\title{
INTEGRATED FOREST RESOURCE MANAGEMENT: A NEW DIRECTION IN SASKATCHEWAN'S FORESTS?
}

MICHAEL FINLEY, 41026 Street W, Saskatoon, SK. S7L OH9

According to Saskatchewan Environment and Resource Management, "the people of Saskatchewan want their forests managed differently than in the past." "The challenge," it says, "is to apply the principle of sustainable development to the management of Saskatchewan's forests." The cornerstone of its new forest policy, unveiled in March 1995, is the Saskatchewan Longterm Integrated Forest Resource Management Plan. The Plan promises an "ecosystem approach" to provide "multiple benefits" that will be "shared among all uses ... large and small, consumptive and nonconsumptive, commercial and noncommercial." Environmental Impact Assessments (EIA) of the Forest Management Licensing Agreements (FMLA) under which major timber harvesters operate will be required for the first time. Is a new era in forest management really beginning? Certainly, Integrated Forest Resource Management (IFRM) is an idea that opens the door to a more ecologically enlightened forest policy. Both governments and the forest industry across Canada are publicly committed to sustainable development. But as Paul Griss, former executive director of the Canadian Nature Federation, warns, "the really tough decisions have yet to be made."

The Saskatchewan IFRM Plan recognizes most of the major stresses on the boreal ecosystem environmentalists and naturalists have been talking about for years. It addresses a wide range of issues and suggests "actions" for five- and 20 -year planning. However, the "actions" are not prescriptions so much as a list of topics for further discussion. For example, under the "objective" entitled "Ensure that timber harvesting and silvicultural practices maintain forest diversity and healthy forest ecosystems," ten "actions" are proposed. The following three are given an "essential" priority:

1.1 In consultation with all stakeholders in a given region, set objectives for the proportions of the land available for intensive management as opposed to more extensive management.

1.2 Review and modify the riparian buffer guidelines to include ... buffer widths required for all bodies of water ... [and] renewal strategies for riparian forests.

1.3 In consultation with all stakeholders, develop guidelines which identify timber harvesting and silviculture objectives ... to address the following issues: Maintaining the natural pattern of landscape diversity; Maintaining a variety of disturbance sizes, ... natural proportions of old stands [and] ... suitable habitat conditions 
for all types of wildlife; ... Avoiding disturbance of rare plants; ... Maintaining corridors of intact forest ... [and] habitat diversity within cut areas; [Establishing] ... preharvest silvicultural prescriptions; ... Modifying harvesting practices [to incorporate] ... forest landscape design principles.

Consultation and public involvement should be part of the planning process, but we have to remember that the forest industry's "consultation" will include efforts to influence public opinion and lobby government. The real test of the new policy will be the way it is applied in the forest management plans drafted by the industry as part of the FMLA's that govern their activities. The guidelines issued by SERM for environmental assessment of management plans are very general. The IFRM plan is mentioned in them only as "background information." Thus the industry has an opportunity to shape the EIA process. Obviously, much will depend on the way the industry interprets and applies IFRM. Major forest companies are now undertaking EIA's. They will be the fulcrum on which the future of our forests turns.

To be acceptable to environmentalists, IFRM must sustain the forest ecosystem in all its diversity. However, there are versions of IFRM with substantial support in industry that place emphasis on sustained harvest of timber. Biological and landscape diversity would be preserved only when it is possible to do so without interfering with the priority given to the forest industry.

Sustained development is a longterm project. Success will be measured over cycles of 75 years or more, the generations of the forest.
Market-driven corporate planning takes a shorter view. North American industry is more closely attuned to the quarterly balance sheet than to the life of the forest, and amortizes capital investments over 10- to 25year periods, not generations of trees. The industry likes to give itself credibility by reminding us that it is "here to stay," with a vested interest in sustaining the resource. But investors are more interested in today's profits than those of their grandchildren. Many people in the industry sincerely care about the future of the forest, but it would be unrealistic to believe that good intentions are a match for the bottom line. As William Osborne observed in a review of the American forest industry: "Like their counterparts in business across the country, pulp and paper mill executives are loathe to spend money on items they feel will not contribute directly to increases in profit or production."

Sustained development will be accepted by the industry as a cost of doing business, not an investment in the future. The cost can be justified to shareholders only if it is imposed on the industry by the public as owners of the resource. Consider the problem of regenerating the forest after harvest. SERM statistics show that $66 \%$ of forest lands harvested since 1975 have failed to regenerate to accepted standards. Industry did as much as was demanded of it; because the regulatory system in place asked no more, the backlog of "not sufficiently stocked" forest land grew. Now that the problem has been recognized by government, industry is willing to improve the silviculture effort. But the driving force is not fear of actually running out of trees. Stands planted today will not be harvested for 75 years, if ever. A more short-term calculation has been 
made: if the regeneration rate is not improved, more stringent harvest limits may be imposed by the regulators.

Exploitation of timber resources is accelerating. The harvest fluctuates with the market for wood, but in each economic cycle, production has reached new highs. In 1979, the harvest in Saskatchewan reached $2,510,000 \mathrm{~m}^{3}$ of wood; at the next peak in $1988,3,818,000 \mathrm{~m}^{3}$ were cut. In 1993, the harvest reached $4,400,000 \mathrm{~m}^{3}$. The size of the harvest is limited by the "allowed cut," a figure that is supposed to insure that the harvest is less than new growth and depletions from fire. In recent years, the harvest of white spruce and other softwoods (the most valuable trees in our forests) has exceeded $85 \%$ of the allowed cut, and a large part of the reserve supply is in inaccessible areas. Worse yet, regeneration failure has not been fully taken into account in setting the allowed cut. SERM's research shows that timber stocks will decline by about one-third over the next rotation of the harvest if management practices do not change.

We can expect industry to try to persuade us that harvest volumes can be maintained. They will likely argue that:

(1) There is room for conservation within the commercial zone without significant reduction in the allowed cut or land base available for the harvest by making minor changes in harvest methods.

(2) There is an excess of old forest at present. Representative old forest would be adequately protected by establishing reserves without changing the "rotation age" at which trees are cut or distribution of the harvest elsewhere.
(3) Even if the land base for the harvest is reduced to some extent, improved silviculture and intensive management can increase yields in the future, making substantial reduction in the allowed cut unnecessary.

These strategies may be compatible with the broad language used in the Saskatchewan Long-term IFRM Plan, but they would not sustain the boreal ecosystem as a functioning whole.

Measures such as wider "leave" strips about lakes and streams do not involve much expense, and do not significantly reduce the harvest. They can be accommodated within IFRM designed to maximize the timber harvest. But simple fixes like these may help maintain populations of some game animals, but they are not enough to preserve the complexity of the boreal ecosystem. In fact, there is good evidence that small leave strips may actually be detrimental. Birds nesting in leave strips are subject to high rates of predation. Predators concentrated in islands and strips of forest eliminate prey and begin to feed on one another. Unfortunately, it will not be easy to make room for more extensive changes in the harvest. If large buffers, small patterned cuts, and extensive stands of mature woodland are required, the land base for harvesting might be reduced, and the cost of harvesting increased.

It would be particularly difficult to preserve old spruce and spruce-fir forest in the commercial zone without major changes in harvesting methods. Some might be left in riparian buffers, but this would not provide the large blocks of intact forest necessary for many old forest denizens. We can expect proponents of minimized IFRM to advocate 
preserves as the principal solution to the old forest problem. The commercial zone would be insulated from the problem by segregating old forest in preserves. Preserves can play a useful role, but if old forest is relegated to them, the diversity of the forest as a whole is destroyed. If old forest is to play its role as a refugia for boreal wildlife, it must be dispersed throughout the forest in a natural pattern. Preserves all too easily become isolated "islands of extinction."

At present, intensive management is not an important part of forestry in Saskatchewan, but it has long been advocated by industry and government as a means of increasing yield. In the 1980s, there was interest in very large-scale intensive management: commercial forests would be managed like agricultural crops. Pure stands of commercially valuable, genetically improved trees would be planted and tended using fertilizers and herbicides (to "weed" undesirable hardwoods). Intensive management of a part of the commercial forest remains attractive to industry as a tradeoff that would allow cut limits to be preserved even if the land base for the harvest is reduced.

There are two serious objections to heavy reliance on intensive management. In the first place, an intensively managed forest is not a natural ecosystem. Biodiversity is inevitably decreased. Use of herbicides to "weed" stands is unacceptable, and not allowed in Saskatchewan at present. Herbicides risk contamination of the environment, but perhaps even more important, drastically alter natural vegetation. Aspen browse used by deer and other animals is reduced, for example. In Sweden, where intensive management has been practiced on a large scale since the late 1960s, significant declines in biodiversity and the extirpation of old forest plants and animals have been reported.

The second problem with intensive management is that it may not work. Early release of softwood by removing competing aspen has been tried in Saskatchewan, but with mixed results. In a controlled experiment in Nova Scotia, trees in thinned stands developed to merchantable size more quickly, but the total yield at optimal rotation age was higher in unthinned stands. Other studies in eastern Canada suggest that spruce and fir actually develop better with the protection of "competing" hardwoods than without it.

It is surprising that advocates of intensive management reject fears that herbicides have residual effects on wildlife because such effects have not been "scientifically proven," while advocating methods of yield improvement that are equally unproven. The paradox is perhaps explained by the fact that promises of improved yield, not actual results, are all that is required to argue that intensive management will sustain heavy harvesting and high cut limits.

Short of business as usual, the version of IFRM sketched above is a worst-case scenario for environmentalists. It can be hoped that industry will offer more to protect the boreal ecosystem. It is possible to do much better. A good model for environmentalists is an approach that has been called "natural forest landscape strategy (NFLS)." NFLS is based on maintaining the full range of natural forest ecosystems throughout the working forest:

"This approach is epitomized by 'a 
lighter approach,' with more attention to natural regeneration and longer rotations for most of the land base. Management of all resources, including water quality, timber and habitats for all species will be included. Aesthetics would flow naturally out of good planning and cut block design. ... Clearcuts will be carried out, but in a range of sizes to emulate natural disturbance patterns. ... Within clearcut disturbance patches, forest ecosystems will be regenerated in size and pattern emulating natural systems."

This is not an unrealistic option. The proponents of NFLS argue that it is both an ecological and economic mistake to copy European intensive management in Canada:

"In Canada we have no shortage of land, a very sparse population, and slow growth rates which make for low returns on intensive silviculture at many sites. Forest landscape management requires more planning, a lower intensity of land use, but more total area in use. ... We have one of the few countries where such an extensive forest management approach makes economic sense. It maintains Canada's competitive position and yet is a 'green' approach."
But if we hope to see the new forest policy that effectively protects the boreal forest, we will have to work hard to get it. Environmentalists can no longer afford to advocate sustainable development in general, woolly terms. Industry will put the best face possible on its proposals for the future. If the debate does not go beyond slogans, the public will all too readily accept anything the industry offers under the banner of sustainable development. Environmentalists must be prepared to critically assess the industry's version of IFRM presented in EIAs and Forest Management Plans. As industry and government move from the general to the specific, so must environmentalists.

\section{Further Reading}

Canada Forest Service and SERM, Forestry Branch. 1995. Saskatchewan long-term integrated forest resource management plan.

GRISS, Paul. 1993. "Implementing sustainable forests: a Canadian commitment." Forest Chronicle 69:535.

OSBORNE, William. 1974. The paper plantation. Viking Books.

BOOTH, D.L., D.W.K. BOULTER, D.J. NEAVE, A.A. ROTHERHAM and D.A. WELSH. 1993. "Natural forest landscape management: a strategy for Canada." Forest Chronicle 69:141-145

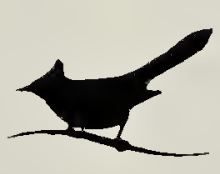

The Prairie Rattlesnake is of considerable economic value to the farmer as it feeds on grain-destroying pests such as rats, mice and other small rodents. Froom, Barbara. The Snakes of Canada. 